International Research Journal of Management, IT \& Social Sciences
Available online at https://sloap.org/journals/index.php/irjmis/
Vol. 9 No. 1, January 2022, pages: 99-96
ISSN: 2395-7492
https://doi.org/10.21744/irjmis.v9n1.2009

\title{
Analysis of Factors Affecting Motor Vehicle Tax Revenue (South Sumatra Province 2006-2020)
}

\begin{tabular}{|c|c|}
\hline & $\begin{array}{r}\text { M. Hasan Basri } \\
\text { Isnurhadi }^{\mathrm{a}} \\
\text { Marlina Widiyanti }^{\mathrm{c}} \\
\text { Mohamad Adam }^{\mathrm{d}}\end{array}$ \\
\hline Article history: & Abstract \\
\hline $\begin{array}{l}\text { Submitted: } 09 \text { October } 2021 \\
\text { Revised: } 18 \text { November } 2021 \\
\text { Accepted: } 27 \text { December } 2021\end{array}$ & $\begin{array}{l}\text { This study aims to determine the effect of changes in investment, } \\
\text { consumption, DGFB per capita, inflation on motor vehicle tax revenues in } \\
\text { South Sumatra Province. Motor vehicle tax revenues were sampled with the } \\
\text { research period 2006-2020. The research used the multiple linear regression } \\
\text { method. The results showed that changes in investment, consumption, and } \\
\text { inflation did not significantly affect motor vehicle tax revenues in South }\end{array}$ \\
\hline \multirow[t]{2}{*}{$\begin{array}{l}\text { Keywords: } \\
\text { changes in consumption; } \\
\text { DGFB per capita; } \\
\text { inflation; } \\
\text { investment change; } \\
\text { Motor Vehicle Tax (VTR); }\end{array}$} & $\begin{array}{l}\text { Sumatra in 2006-2020. Meanwhile, DGFB per capita has a significant positive } \\
\text { effect on motor vehicle tax revenues in South Sumatra in 2006-2020. These } \\
\text { results indicate that an increase in the income of the people of South Sumatra } \\
\text { will encourage tax compliance, one of which is the motor vehicle tax. These } \\
\text { results clarify that an increase in income will encourage people to be more } \\
\text { aware of their obligations. An increase in income apart from tax compliance } \\
\text { can also be associated with increased motor vehicle purchases. The more the } \\
\text { number of motorized vehicles, the more tax revenue from these vehicles also } \\
\text { increases following the tax theory that has been put forward. }\end{array}$ \\
\hline & $\begin{array}{r}\text { International research journal of management, IT and social sciences (C) } 2022 . \\
\text { This is an open access article under the CC BY-NC-ND license } \\
\text { (https://creativecommons.org/licenses/by-nc-nd/4.0/). }\end{array}$ \\
\hline $\begin{array}{l}\text { Corresponding author: } \\
\text { M. Hasan Basri, } \\
\text { Master of Management, } \\
\text { Email address: muhamm }\end{array}$ & $\begin{array}{l}\text { rsity, Palembang, Indonesia. } \\
\text { a gmail.com }\end{array}$ \\
\hline
\end{tabular}

Master of Management, Sriwijaya University, Palembang, Indonesia

Lecturer of Magister Management, Economic Faculty, Sriwijaya University, Palembang, Indonesia

Lecturer of Magister Management, Economic Faculty, Sriwijaya University, Palembang, Indonesia

Lecturer of Magister Management, Economic Faculty, Sriwijaya University, Palembang, Indonesia 


\section{Introduction}

The history of regional autonomy in Indonesia has started since the Dutch colonial era. If defined broadly, regional autonomy is the rights and authorities of the regions regulated by legislation to regulate their regions to aim at the prosperity of the area's residents. One of the instruments to fund regional autonomy is the revenue generated by the regions. According to the Directorate General of Fiscal Balance, the region's original regional income is income obtained, which is collected according to regional provisions following statutory regulations.

According to data from the Directorate General of Fiscal Balance (DGFB), as of 2020, the largest source of regional income is regional taxes, and one of the conditions is the motor vehicle tax (Montag, 2015; Delucchi, 2007). The motor vehicle tax realization in South Sumatra fluctuates yearly, sometimes reaching the set target, sometimes not. Motor Vehicle Tax can increase and support local household budget revenues. Factors influencing motor vehicle tax revenues are investment and consumption, DGFB, and inflation (Svensson, 1997).

Other studies have also raised this theme, and the results of previous studies show a diversity of research gaps in the conclusions expressed. Research conducted by Rahayu \& Kustina (2019) and Ginting (2015), for example, proves that consumption increases motor vehicle tax revenues through increased motorcycle purchases. At the same time, the research conducted by Marpaung and Bastari, (2018) shows that there is no evidence that consumption affects tax revenue (Carbajo \& Faiz, 1994).

Research by Sari et al. (2020), Kartika (2020), Munawir et al. (2017), Ratnasari (2016), Ginting (2015), Dini (2015), conclude that DGFB has a significant positive effect on tax revenue. Different results that conclude that DGFB has no effect research from Apriliyanti (2021), Lumy et al. (2021), Mustakim et al. (2016). The inflation variable also has different effects based on previous research. Research by Apriliyanti (2021), Puspita et al. (2020), shows that inflation does not affect tax revenue. Another result was obtained by Lumy et al. (2021), who found that inflation had a significant positive effect. Previous research has examined the factors that affect the tax increase the vehicle motor. Based on this, several variables studied that become a factor in increasing taxes are consumption, investment DGFB per capita, inflation (Gonçalves \& Salles, 2008; Bruno \& Easterly, 1998).

\section{Materials and Methods}

The type of data used in this research is secondary data. Secondary data is data taken indirectly or ready-made data obtained from other parties. This research data is from various sources such as the Regional Revenue Agency of South Sumatra, the Central Statistics Agency (CSA), and others. The research sample is South Sumatra VTR receipts, with 2006-2020 representing VTR acceptance under study.

The dependent variable in this study is motor vehicle tax revenue in South Sumatra. The independent variable in this study are the factors that cause the acceptance of VTR to change. The predicted variables used in this study are changes in investment, consumption, DGFB per capita, and inflation (Nasir et al., 2019).

Data analysis such as descriptive statistics, F-test, and t-test were used in this study to see the role of the independent variable on the dependent. Descriptive analysis is an analysis that used for shared reflection or description of the shape of something information can we analysis of the value of the centralization of data (mean), maximum value, minimum value, the value of ancillary data (standard deviation), the value of the difference or range you, the value of sum and value skewness or skewness of the data. Descriptive analysis aims to share illustrations of the information presented in studies (Ferdinand, 2014).

The data analysis technique used in this research is multiple linear regression. Multiple linear regression looks at changes in the predictor variable in predicting the movement of the dependent variable. The regression equation made in this research is:

$$
\mathrm{Y}=\beta 0+\beta 1 \mathrm{X}_{\text {Change_investation }}+\beta 2 \mathrm{X}_{\text {Change_Consumption }}+\beta 3 \mathrm{X}_{\mathrm{GRDP}}+\beta 4 \mathrm{X}_{\text {Inflation }}+\mathrm{e}_{\mathrm{i}}
$$

Basri, M. H., Isnurhadi, I., Widiyanti, M., \& Adam, M. (2022). Analysis of factors affecting motor vehicle tax revenue (South Sumatra Province 2006-2020). International Research Journal of Management, IT and Social Sciences, 9(1), 90-96. https://doi.org/10.21744/irjmis.v9n1.2009 


\section{Results and Discussions}

Table 1

Descriptive statistics

\begin{tabular}{|c|c|c|c|c|c|}
\hline Variable & $\mathrm{N}$ & Minimum & Maximum & Mean & Std. Deviation \\
\hline $\begin{array}{l}\text { Investment Change (billion } \\
\text { Rp) }\end{array}$ & & -2410 & 7401.3 & 1011.53 & 2428 \\
\hline Consumption Change (Rp) & 15 & -11260 & 108 & 521 & 34943 \\
\hline ta (Rp) & & 13812808 & 53550 & 330085 & 14351947 \\
\hline & & 15 & & & 3.03594 \\
\hline $\begin{array}{l}\text { Motor Vehicle Tax } \\
\text { Revenue Realization (IDR) }\end{array}$ & & 93,641 & 56 & $982,393,694$ & $7,798,167$ \\
\hline
\end{tabular}

The description of each variable can be seen in table 1 above, such as the maximum, minimum, average (mean), and standard deviation values. Variables with a suitable data distribution are seen from the average value, greater than the standard deviation, whereas a significant standard deviation value indicates anything that is not good.

F-Test (F-Test)

The variables used are transformed into natural log form $(\mathrm{Ln})$ to be free from the classical assumption problem. The $F$ test can test the combined effect of the independent variable on the dependent variable. The basis for decision making is seen from the F value from the SPSS output ANOVA table, where if the P-value of less than 0.05 and Fount is greater than Ftable, the proposed model is significant.

Table 2

F- test results

\begin{tabular}{cc}
\hline Mark & Coefficient \\
\hline $\mathrm{F}_{\text {count }}$ & 87,951 \\
$\mathrm{~F}_{\text {table }}$ & 3.48 \\
Sig & 0.000 \\
\hline Source: & SPSS output data processing
\end{tabular}

Source: SPSS output data processing

Based on table 2 above, it can be concluded that changes in consumption, investment, DGFB per capita, and inflation have a significant effect on motor vehicle tax revenues (VTR) in South Sumatra.

Individual parameter significance test ( $t$-Test)

The t-test, which is one type of inferential statistics, is used to measure the effect of the independent variables individually on the dependent variable. The basis for deciding whether or not the effect is the same as the F test is comparing the value of the table with count and comparing the probability value or SigSig. With a significance level of $5 \%(0.05)$.

Table 2

Significance test results

\begin{tabular}{|c|c|c|c|c|c|}
\hline \multirow[t]{2}{*}{ Model } & \multicolumn{2}{|c|}{$\begin{array}{c}\text { Unstandardized } \\
\text { Coefficients }\end{array}$} & \multirow{2}{*}{$\begin{array}{c}\begin{array}{c}\text { Standardized } \\
\text { Coefficients }\end{array} \\
\text { Beta }\end{array}$} & \multirow[t]{2}{*}{$\mathrm{t}$} & \multirow[t]{2}{*}{ Sig. } \\
\hline & $\mathrm{B}$ & Std. Error & & & \\
\hline (Constant) & 8,221 & 1,408 & & 5.838 & 0.000 \\
\hline LnChangeInvest & 0.009 & 0.019 & 0.029 & 0.486 & 0.638 \\
\hline LnChangeConsumption & 0.027 & 0.021 & 0.080 & 1,299 & 0.223 \\
\hline
\end{tabular}




\begin{tabular}{crrrrr}
\hline LnPDRBPerCapital & 1.077 & 0.074 & 0.979 & 14.618 & 0.000 \\
LnInflation & -0.038 & 0.054 & -0.047 & -0.707 & 0.496 \\
\hline Source: SPSS output data processing & & & & &
\end{tabular}

Source: SPSS output data processing

Multiple linear regression equations that can be made based on the table above are as follows:

$$
\mathrm{Y}_{\mathrm{lnPKB}}=8,221+0.009 \text { LnChange in Investment }+0.027 \text { LnChange in Consumption }+1.077 \text { LnGDPPer Capita }-0.038 \text { LnInflation }
$$

The following is an explanation of the effect of each variable and an explanation of the regression equation above:

a) The first number, 8,221, is constant, and the number of dependent variable values if all independent variables are 0 . Graphically, constants are equivalent to the $\mathrm{Y}$-intercept of the regression line crossing the $\mathrm{Y}$-axis.

b) Based on the table above, the investment change variable has a count value of 0.486 , smaller than the specified table, 2.28. The probability value or SigSig. The change in investment shows a number greater than the specified significance level of $0.05(5 \%)$. The conclusion of the two statements shows that the variable of investment change has no significant effect on motor vehicle tax revenue (Zubair et al., 2020). Based on these conclusions, the proposed hypothesis 1 was rejected because there was no effect of changes in investment on motor vehicle tax revenues. The value of 0.009 in the regression equation above shows the value of the sensitivity or slope of the change in investment to the motor vehicle tax. A positive value indicates that an increase in the value of the change in investment will change the value of the CLA in a unidirectional manner. A value of 0.009 can be interpreted if the change in consumption changes by $1 \%$ or one unit will change $0.009 \%$ of VTR in the same direction. Suppose the change in investment increases, then the PKB increases and vice versa with the assumption that the other variables are 0 .

c) The consumption change variable also shows the count value, which is only 1.299 , which is smaller than table 2.28 and the sig value. 0.223 is more significant than 0.05 . Changes in consumption were also found to have no significant effect on motor vehicle tax revenues. Hypothesis 2 proposed is also rejected because there is no effect of changes in consumption on motor vehicle tax revenues. The variable of consumption change has a sensitivity value or slope of 0.027 to the motor vehicle tax. The value of 0.027 indicates that if the change in consumption changes by $1 \%$ or one unit, the motor vehicle tax will change by $0.027 \%$. Based on the regression equation, the value of the slope of consumption changes is positive, which means that changes in consumption changes will change VTR in the same direction.

d) DGFB per capita based on table 4.8 above shows the count value of 14.618 , greater than t-table 2.28. Probability or SigSig. also shows a value smaller than the specified significance level of 0.05 . If it is seen that the coefficient value is positive, it shows that changes in motor vehicle tax revenue will be influenced in the same direction by changes in per capita. These results indicate that the proposed hypothesis 3 is accepted because it found a significant positive effect of DGFB per capita on motor vehicle tax revenues. The DGFB per capita variable also shows a positive slope value or variable sensitivity. This value indicates that the higher or increasing DGFB per capita of South Sumatra, the motor vehicle tax revenue of South Sumatra also increases. The sensitivity or slope of GDFB per capita is 1.077, indicating that if DGFBper capita changes by $1 \%$ or one unit, then motor vehicle tax revenues will change by $1.077 \%$ or $1.077 \mathrm{x}$.

e) The inflation variable was found to have no significant effect on motor vehicle tax revenue (VTR). The statement based on the results of the output table above shows the inflation count value of -7.07 , which is smaller than table 2.28 and the value of SigSig. 0.496, which is greater than the 0.05 level. Hypothesis 4 is rejected because although the direction indicated by inflation is harmful based on the coefficient value, the effect is not significant. The sensitivity value or inflation slope when referring to the above equation is -0.038 . The minus number indicates that a change in one variable will change another variable in the opposite direction. Rising inflation will reduce motor vehicle tax revenues and vice versa. Inflation that increases by $1 \%$ or one unit will increase or decrease motor vehicle tax revenues $-0.038 \%$ or $-0.038 \mathrm{x}$.

The study results conclude that changes in investment do not significantly affect motor vehicle tax revenues in South Sumatra from 2006-2020. These results indicate that an increase or decrease in investment in South Sumatra will not directly change the amount of VTR revenue (Sintani et al., 2021). This conclusion is not following the proposed hypothesis 1 . Therefore, hypothesis 1 is rejected. High or increased investment is expected to increase taxpayers' income so that the level of tax compliance increases, one of which is the fulfillment of VTRtax obligations. The

Basri, M. H., Isnurhadi, I., Widiyanti, M., \& Adam, M. (2022). Analysis of factors affecting motor vehicle tax revenue (South Sumatra Province 2006-2020). International Research Journal of Management, IT and Social Sciences, 9(1), 90-96. https://doi.org/10.21744/irjmis.v9n1.2009 
different results from the hypothesis allow for an indirect effect that may occur compared to the direct effect of the variable. Investment may indirectly affect income, affecting tax revenue, which is motor vehicle tax. This result contradicts the theory put forward in the previous chapter, where investment is hypothesized to affect motor vehicle tax revenue directly.

Based on the study results, it was also found that changes in consumption did not have a significant effect on motor vehicle tax revenues in South Sumatra in 2006-2020. Hypothesis 2, which states a significant positive effect of changes in consumption on motor vehicle tax revenues, is rejected because it does not follow the study results (Girod \& De Haan, 2009; Qiao et al., 2009). Changes in consumption are the same as changes in investment because they may have an indirect effect or need a mediator variable to conclude an effect (Sari \& Yasa, 2021). This result is also different from previously proposed hypotheses and related theories. Similar results were also shown in the study of Febriani (2018), which states whether or not the effect of consumption on increasing vehicle taxes.

The research results described previously concluded that DGFB per capita had a significant positive effect on motor vehicle tax revenues in South Sumatra in 2006-2020. These results indicate that an increase in the income of the people of South Sumatra will encourage tax compliance, one of which is the motor vehicle tax. These results clarify that an increase in income will encourage people to be more aware of their obligations. An increase in income apart from tax compliance can also be associated with increased motor vehicle purchases. The more the number of motorized vehicles, the more tax revenue from these vehicles also increases following the tax theory that has been put forward. The results also follow Peacock and Wiseman's theory which states that an increase in income will lead to higher public spending. The intended public expenditure is the expenditure of tax obligations for taxpayers, which will increase along with the increase in income. This result is supported by the theory and several previous studies such as Sari et al. (2020), Lumy et al. (2021), Kartika (2020), Munawir et al. (2017), Ratnasari (2016), Ginting (2015), Dini (2015), Ariasih et al. (2013).

The inflation variable, which is hypothesized to have a significant adverse effect, is not proven. Therefore hypothesis 4 is rejected. The rejection of the hypothesis is based on the conclusion of the research that has been described previously that there is no significant effect of inflation on motor vehicle tax revenues in South Sumatra in 2006-2020. These results also align with the previously stated theory that underlies the hypothesis. If it is reflected that income will increase tax revenue, on the contrary, inflation that breaks down income will reduce the tax revenue obtained. Inflation is a periodic increase in prices. If it increases and is not accompanied by an increase in income, the income earned by the community will be prioritized for consumption or other basic needs. The implicit decline in income due to inflation will reduce taxpayer compliance because fulfillment priorities shift and focus more on fulfilling more essential principles. Similar results were also obtained by several previous researchers, such as the research of Apriliyanti (2021), Puspita et al. (2020), Munawir et al. (2017), Dini, (2015).

\section{Conclusion}

This study concludes that changes in investment, consumption, and inflation did not significantly affect motor vehicle tax revenues in South Sumatra in 2006-2020. Meanwhile, GRDP per capita has a significant positive effect on motor vehicle tax revenues in South Sumatra in 2006-2020

\section{Conflict of interest statement}

The authors declared that they have no competing interests.

\section{Statement of authorship}

The authors have a responsibility for the conception and design of the study. The authors have approved the final article.

\section{Acknowledgments}

Authors thank all supports and authorship feedbacks from academic support, similarly to financial aid from the university. Without those supports, this project can be done as planned. 


\section{References}

Apriliyanti, D. A. K. (2021). Strategi Peningkatan Pajak Kendaraan Bermotor di Provinsi Kalimantan Selatan (Doctoral dissertation, IPB University).

Ariasih, P., Utama, I. M. S., \& Wirathi, I. G. A. P. (2013). Pengaruh Jumlah Penduduk dan PDRB per Kapita terhadap Penerimaan PKB dan BBNKB serta Kemandirian Keuangan Daerah Provinsi Bali Tahun 1991-2010. Udayana University.

Bruno, M., \& Easterly, W. (1998). Inflation crises and long-run growth. Journal of Monetary economics, 41(1), 3-26. https://doi.org/10.1016/S0304-3932(97)00063-9

Carbajo, J., \& Faiz, A. (1994). Motor vehicle emissions control: some policy options for developing countries. Science of the total environment, 146, 11-18. https://doi.org/10.1016/0048-9697(94)90214-3

Delucchi, M. A. (2007). Do motor-vehicle users in the US pay their way?. Transportation Research Part A: Policy and Practice, 41(10), 982-1003. https://doi.org/10.1016/j.tra.2007.06.001

Dini, S, 2015. Analisis Jumlah Kendaraan Bermotor, PDRB, Jumlah Penduduk dan Inflasi Yang Mempengaruhi Pajak Kendaraan Bermotor Di Provinsi Sumatera Utara. Jurnal Akuntansi Prima V.

Febriani, F. M. (2018). An Analysis On The Factors Which Influence Motor Vehicle Tax Revenue With Pdrb As Moderating Variable In North Sumatera. International Journal of Public Budgeting, Accounting and Finance, 1(2), $10-10$.

Ferdinand, A. (2014). Metode Penelitian Manajemen: Pedoman Penelitian untuk Penulisan Skripsi Tesis dan Desrtasi Ilmu Manajemen.

Ginting, E. T. B. (2015). Analisis Faktor-Faktor Yang Mempengaruhi Penerimaan Pajak Kendaraan Bermotor Di Indonesia Periode 2008-2012 (Doctoral dissertation).

Girod, B., \& De Haan, P. (2009). GHG reduction potential of changes in consumption patterns and higher quality levels: Evidence from Swiss household consumption survey. Energy Policy, 37(12), 5650-5661. https://doi.org/10.1016/j.enpol.2009.08.026

Gonçalves, C. E. S., \& Salles, J. M. (2008). Inflation targeting in emerging economies: What do the data say? Journal of Development Economics, 85(1-2), 312-318. https://doi.org/10.1016/j.jdeveco.2006.07.002

Kartika, L. (2020). Analisis Faktor-Faktor Yang Mempengaruhi Penerimaan Pajak Kendaraan Bermotor di Provinsi Sulawesi Selatan (Doctoral dissertation, UNIVERSITAS NEGERI MAKASSAR).

Lumy, D. G., Kindangen, P., \& Engka, D. S. (2021). Analisis Faktor-Faktor Yang Mempengaruhi Penerimaan Pajak Daerah Pada Pemerintah Provinsi Sulawesi Utara. Jurnal Pembangunan Ekonomi Dan Keuangan Daerah, 19(2), 1-16.

Montag, J. (2015). The simple economics of motor vehicle pollution: A case for fuel tax. Energy Policy, 85, 138-149. https://doi.org/10.1016/j.enpol.2015.05.020

Munawir, M., Jamal, A., \& Seftarita, C. (2017). Variabel Ekonomi Makro Yang Mempengaruhi Penerimaan Pajak Kendaraan Bermotor Dan Bea Balik Nama Kendaraan Bermotor Di Aceh. Jurnal Ekonomi dan Kebijakan Publik Indonesia, 4(2), 101-117.

Mustakim, F. R., Hidayat, M. S., \& Rahmadi, S. (2016). Analisis Penerimaan Pajak Kendaraan Bermotor (PKB) di Provinsi Jambi. Jurnal Paradigma Ekonomika, 11(1).

Nasir, M. A., Huynh, T. L. D., \& Tram, H. T. X. (2019). Role of financial development, economic growth \& foreign direct investment in driving climate change: A case of emerging ASEAN. Journal of environmental management, 242, 131-141. https://doi.org/10.1016/j.jenvman.2019.03.112

Puspita, Y., Wicaksono, G., Kusumaningrum, N. D., Asmandani, V., \& Boedijono, B. (2020). The Role of Population, Inflation and Economic Growth of Local Tax Revenues in East Java Province, Indonesia.

Qiao, Z., McAleer, M., \& Wong, W. K. (2009). Linear and nonlinear causality between changes in consumption and consumer attitudes. Economics Letters, 102(3), 161-164. https://doi.org/10.1016/j.econlet.2008.12.010

Rahayu, N. P. I., \& Kustina, K. T. (2019). Pengaruh Penerapan Pajak Progresif dan Perilaku Konsumtif Wajib Pajak dalam Pembelian Kendaraan Bermotor terhadap Pendapatan Asli Daerah Provinsi Bali UPT. Samsat di Kota Denpasar. WACANA EKONOMI (Jurnal Ekonomi, Bisnis dan Akuntansi), 18(2), 98-103.

Ratnasari, R. (2016). Analisis Penerimaan Pajak Kendaraan Bermotor Di Provinsi Sulawesi Tenggara. JPEP (Jurnal Progres Ekonomi Pembangunan), 1(1).

Sari, A. P., Saleh, M., \& Suharto, R. B. (2020). Pengaruh Jumlah Penduduk Dan Produk Domestik Regional Bruto Terhadap Pajak Kendaraan Bermotor Di Provinsi Kalimantan Timur. Jurnal Ilmu Ekonomi Mulawarman (JIEM), 4(4).

Basri, M. H., Isnurhadi, I., Widiyanti, M., \& Adam, M. (2022). Analysis of factors affecting motor vehicle tax revenue (South Sumatra Province 2006-2020). International Research Journal of Management, IT and Social Sciences, 9(1), 90-96. https://doi.org/10.21744/irjmis.v9n1.2009 
Sari, M. D. K., \& Yasa, N. N. K. (2021). The role of hedonic consumption tendency mediate the effect of fashion involvement on impulsive buying. International Research Journal of Management, IT and Social Sciences, 8(1), 70-82. https://doi.org/10.21744/irjmis.v8n1.1116

Sintani, L., Fransisca, Y., Anjarini, A. D., \& Mulyapradana, A. (2021). Identification of the effectiveness of higher education marketing strategies using social media. International Research Journal of Management, IT and Social Sciences, 9(1), 1-9. https://doi.org/10.21744/irjmis.v9n1.1994

Svensson, L. E. (1997). Inflation forecast targeting: Implementing and monitoring inflation targets. European economic review, 41(6), 1111-1146. https://doi.org/10.1016/S0014-2921(96)00055-4

Zubair, S., Kabir, R., \& Huang, X. (2020). Does the financial crisis change the effect of financing on investment? Evidence from private SMEs. Journal of Business Research, 110, 456-463. https://doi.org/10.1016/j.jbusres.2020.01.063 